\section{Journal of Sciences and \\ Engineering}

Vol. 5, $\mathrm{N}^{\circ}$ 2, 2021

\title{
Effect of silicon's doses in the cultivation of pea (Pisum sativum $L$.), to obtain a higher yield, district of Barranca [Efecto de dosis de silicio en el cultivo de arveja (Pisum sativum L.), para obtener mayor rendimiento, distrito de Barranca]
}

Henry Christopher Angeles Lostaunado, José Antonio Legua Cárdenasa (iD), Marco Antonio Jamanca Ramirez ${ }^{b}$ (D), Miguel Angel Inga Soteloc (iD), José

Yovera Saldarriagab (iD), Félix Gil Caro Soto ${ }^{a}$ (D), Elvira Teófila Castañeda Chirre $^{a}$ (D), Eugenio Javier Gómez Gamarrad (iD), Dante Daniel Cruz Nietoa, ${ }^{*}$

\author{
aUniversidad Nacional José Faustino Sánchez Carrión, Peru. \\ bUniversidad Nacional Santiago Antúnez de Mayolo, Peru. \\ cUniversidad Nacional de Barranca, Peru. \\ dInstituto de Educación Superior Tecnológico Público "Eleazar Guzmán Barrón" - Huaraz, Peru \\ *daniel2262@hotmail.com
}

Received: 1 August 2021; Accepted: 13 August 2021; Published: 21 August 2021

\section{Resumen}

El objetivo fue determinar la dosis adecuada de fertilización foliar de silicio, para obtener mayor rendimiento en cultivo de arveja. En cuanto la metodología, la investigación es aplicada y experimental; por lo que se empleó el Diseño de Bloques Completamente al Azar comprendido por 4 bloques y 4 tratamientos, los cuales fueron: $\mathrm{T}_{1}=0, \mathrm{~T}_{2}=0.50 \mathrm{~L}, \mathrm{~T}_{3}=0.75 \mathrm{~L}$ y $\mathrm{T}_{4}=1 \mathrm{~L}$ Silicio (Sil Trade)/ $200 \mathrm{~L}$ de agua aplicado en cuatro momentos, cabe mencionar el ingrediente químico de silicio es ácido ortosilícico. Se evaluaron las características físicas desde siembra hasta cosecha y analizaron las concentraciones de silicio en hojas por tratamiento. Obtenidos los datos se procesaron mediante análisis de varianza y Duncan. Los resultados determinaron que $\mathrm{T}_{4}$ sobresalió en altura den planta con $89.74 \mathrm{~cm}$, cantidad de vainas por planta con 37, peso de vainas por planta con $234.43 \mathrm{~g}$, rendimiento con $4444.4 \mathrm{~kg} / \mathrm{ha}$ y concentración de silicio en hojas con $1.75 \mathrm{~g} / 100 \mathrm{~g}$ de materia seca. Se concluye que no hubo efectos de silicio; es decir no influyó estadísticamente en las características físicas. Sin embargo, $\mathrm{T}_{4}$ con $1 \mathrm{~L}$ Silicio (Sil Trade) /200 L de agua aumentó $8.58 \%$ del rendimiento con relación al $T_{1}$.

Palabras clave: Arveja, dosis, silicio, rendimiento

\begin{abstract}
The objective was to determine the adequate dose of silicon foliar fertilization, to obtain a higher yield in pea crops. Regarding the methodology, the research is applied and experimental; Therefore, the Completely Random Block Design comprised of 4 blocks and 4 treatments was used, which were: $\mathrm{T}_{1}=0, \mathrm{~T}_{2}=0.50 \mathrm{~L}, \mathrm{~T}_{3}=0.75 \mathrm{~L}$ and $\mathrm{T} 4=1 \mathrm{~L}$ Silicon (Sil Trade) $/ 200 \mathrm{~L}$ of water Applied in four times, it is worth mentioning the chemical ingredient of silicon is orthosilicic acid. The physical characteristics from sowing to harvest were evaluated and the silicon concentrations in leaves were analyzed by treatment. Obtained data were processed by analysis of variance and Duncan. The results determined that $T_{4}$ stood out in plant height with $89.74 \mathrm{~cm}$, number of pods per plant with 37 , weight of pods per plant with $234.43 \mathrm{~g}$, yield with $4444.4 \mathrm{~kg} / \mathrm{ha}$ and silicon concentration in leaves with $1.75 \mathrm{~g} / 100 \mathrm{~g}$ of dry material. It is concluded that there were no silicon effects; that is, it did not statistically influence the physical characteristics. However, $\mathrm{T}_{4}$ with $1 \mathrm{~L}$ Silicon (Sil Trade) / $200 \mathrm{~L}$ of water increased $8.58 \%$ of the yield in relation to $\mathrm{T}_{1}$.
\end{abstract}

Keywords: Pea, dose, silicon, yield. 


\section{SE \\ Journal of Sciences and Engineering}

Vol. 5, $\mathrm{N}^{\circ} 2,2021$

Copyright (C) 2021, CINCADER.

ISSN 2523-9503

DOI: https://doi.org/10.32829/sej.v5i2.134

\section{Introduction}

Silicon is one of the most abundant elements in the soil and is united with other elements forming different complex compounds in its chemical structure. These compounds influence the development of the plant, according to Michajluk, et al. (2019), mention that silicon is one of the most abundant elements in the earth's crust, it is the majority component of the minerals of the silicate group and is considered an essential element for certain crops. Also Savant, et. to the. (1996) mention that Silicon is found in the soil solution (intensity factor) is highly influenced by its dissolution kinetics, which in turn is influenced by various soil factors such as Al, Fe oxides, matter organic, redox potential and moisture.

Despite the abundance of silicon, all the compounds are not available for absorption by the plant; Therefore, it is required that the silicon is in solution as Monosilicic Acid $\left(\mathrm{Si}(\mathrm{OH})_{4}\right)$ for the availability of its absorption and favors the biochemical development. This assertion is supported by Castellanos, et. to the. (2015), who state that Silicon is present in the soil solution as Monosilicic Acid $\left(\mathrm{Si}(\mathrm{OH})_{4}\right)$, most of it in undissociated form, which is easily available to plants. However, it is important to know the concentration of silicon in the soil; since this nutrient promotes the absorption of other nutrients and therefore there is good development in the plant according to Quero, E. (2008), affirms that in the soil they must be found in values of 100 to $200 \mathrm{mg} / \mathrm{kg}$ of these forms of silicon soluble.

Likewise, silicon is absorbed as Monosilicic Acid $\left(\mathrm{Si}(\mathrm{OH})_{4}\right)$, which favors the development of the plant and reduces stress of pests, diseases and environmental factors; Therefore, the availability of this compound in the soil is important, according to Epstein (1999) concludes that many of these same conditions affect plants in soils poor in silicon and there are such. Taken together, the evidence is overwhelming that silicon should be included among the elements that have the greatest influence on plant life.

However, an efficient alternative to reduce stress problems in pea crops is foliar fertilization, since silicon is absorbed immediately for the strengthening and development of the plant. This statement is based on Molina (2002), who mention that foliar fertilization is the principle of application of nutrients through the foliar tissue, mainly through the leaves, which are the organs where the greatest physiological activity of the plant is concentrated.

Due to this use by means of leaf tissue, silicon fertilization can be applied as silicon dioxide, potassium silicate and together with other chemical compounds such as pesticides that reduce stress problems and at the same time the economic cost, according to De Freitas, et al. (2011) state that potassium silicate is an interesting source of contribution of Silicon, which, applied by foliar route, can facilitate the use of this element by plants, in addition to being applied together with fungicides and insecticides, thus saving on Applications.

It is worth mentioning that this silicon fertilization method is used in most of the farmers of the Barranca District, to reduce the problems caused by stress from environmental and phytosanitary factors and to supply this nutrient due to the deficiency of available silicon compounds in the soil. which is essential for the development of the De Carvalho et. al (2019), state that the nutritional essentiality of silicon is controversial. Some researchers claim that it is essential for plants, while others refer to it as a beneficial nutrient. It also has the effect of reducing phytosanitary problems as investigated by Gómez, et. al (2006), who conclude in their results that the foliar application of silicon and honey to plants modifies the resistance and severity to the attack of pathogens. 


\section{SE \\ Vol. 5, $\mathrm{N}^{\circ}$ 2, 2021 \\ Journal of Sciences and Engineering}

Copyright (C) 2021, CINCADER.

ISSN 2523-9503

DOI: https://doi.org/10.32829/sej.v5i2.134

\section{Materials and Methods}

\section{Location and edaphoclimatic conditions}

The experiment was carried out in the Barranca district, located in the Barranca province, which borders the Buena Vista Human Settlement to the North, the San Ildefonso Cemetery to the South, the Santa Margarita Farm to the West and the Pampa Velarde Town Center to the East. Likewise, it is located at the coordinates of South Latitude: $10^{\circ} 46^{\prime} 05.1^{\prime}$ 'West Longitude: $77^{\circ} 44^{\prime}$ 30.0" Altitude: $84 \mathrm{~m}$ and its experimental area was $576 \mathrm{~m}^{2}$. In the edaphoclimatic conditions, the temperature was between $22^{\circ} \mathrm{C}$ and $25^{\circ} \mathrm{C}$ on average, the relative humidity was $82 \%$ and the soil was sandy loam (See figure 1).

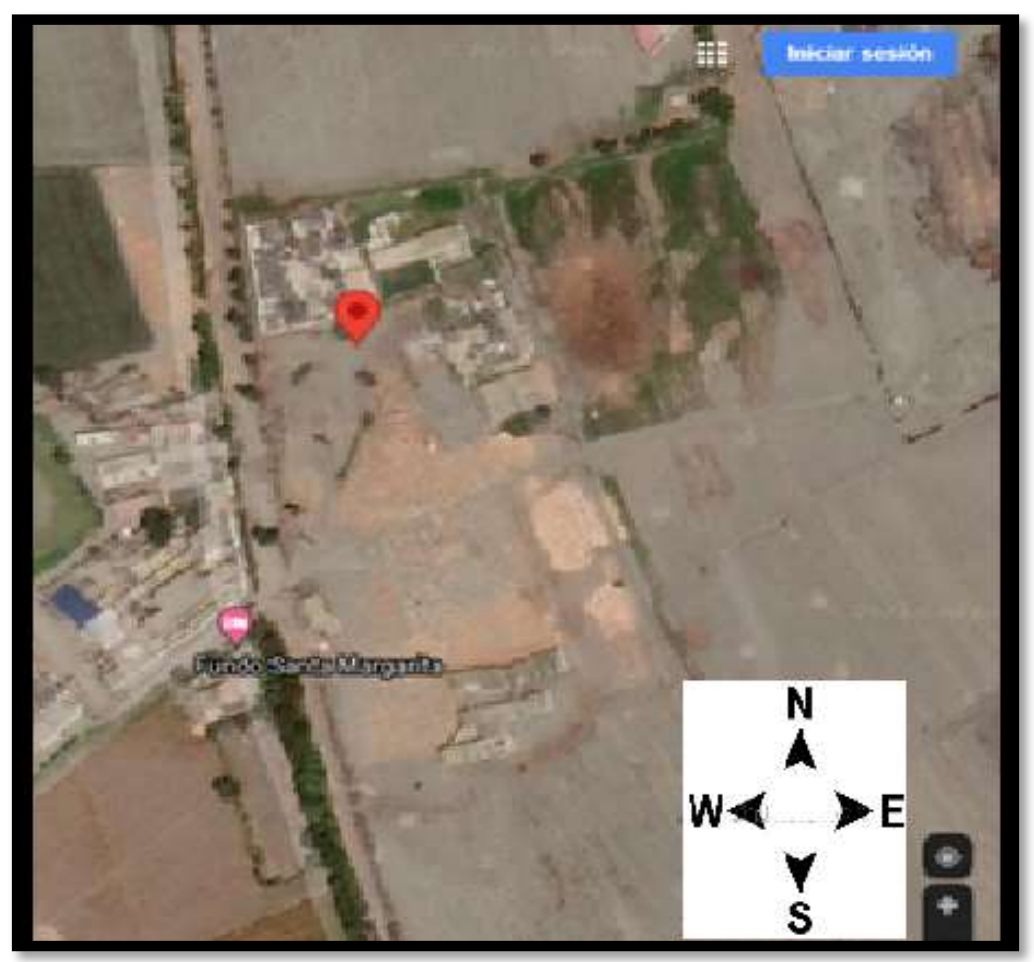

Figure 1: Location map of the experimental area

\section{Soil analysis}

According to the soil analysis carried out in the National Institute of Agrarian Innovation - Huaral (2015) that details table 1, it was determined that the soil has a slightly alkaline $\mathrm{pH}$ with 7.8 (6 7.5), does not present salt problems, low organic matter concentration with $1 \%(2 \%-4 \%)$, nitrogen with $0.05 \%(0.1 \%-0.2 \%)$ and available potassium with $5 \mathrm{ppm}(125 \mathrm{ppm}-250 \mathrm{ppm})$. In medium concentration is available phosphorus with $14 \mathrm{ppm}(12 \mathrm{ppm}-36 \mathrm{ppm})$ and a normal concentration of calcium carbonate. Therefore, this soil is in favorable conditions for the sowing of the pea crop. However, it needs the incorporation of organic matter. 


\section{Journal of Sciences and Engineering}

Vol. 5, $\mathrm{N}^{\circ} 2,2021$

Table 1. Basic soil fertility analysis for pea cultivation

\begin{tabular}{|c|c|c|c|c|c|c|c|c|c|c|c|}
\hline E.C. & $\begin{array}{c}\mathrm{pH} \\
1: 2.5\end{array}$ & O.M. & $\mathrm{N}$ & $P$ & K & $\begin{array}{c}\mathrm{CaCo}_{3} \\
\%\end{array}$ & \multicolumn{4}{|c|}{$\begin{array}{l}\text { Cation exchange } \\
\text { (mEq/100 g soil) }\end{array}$} & CEC \\
\hline $\mathrm{mS} / \mathrm{cm}$ & & $\%$ & $\%$ & Ppm & $\mathrm{ppm}$ & & $\mathrm{Ca}$ & $\mathrm{Mg}$ & $\mathrm{Na}$ & $\mathrm{K}$ & \\
\hline 0.32 & 7.80 & 1.00 & 0.05 & 14 & 5 & 1.32 & 12.34 & 0.12 & 0.13 & 0.01 & 12.60 \\
\hline
\end{tabular}

Source: INIA (2015), Basic soil fertility analysis.

Note: E.C: Electrical conductivity

O.M.: Organic matter

$\mathrm{mEq}$.: Milli equivalent

CEC: Cation exchange capacity

Ppm: Parts per million

\section{Silicon in soil}

Regarding the total concentration of silicon compounds detailed in table 2 , this result was obtained by means of the atomic absorption spectrophotometry procedure of the Perkin Elmer brand in the INIA-Huaral laboratory (2015), which was determined by $12.12 \mathrm{mg} / \mathrm{L}$ of solution were obtained. Therefore, this result shows that it is within the normal rating of $5-150 \mathrm{mg} / \mathrm{L}$ of solution according to (Zagal et al., 2007). But this result is from the total of silicon compounds found in solution and not from the single silicon. Therefore, this concentration of this element has a low tendency and for this reason foliar application of silicon is required in pea crops.

Table 2. Determination of Silicon in soil

\begin{tabular}{cccc}
\hline Element & $\begin{array}{c}\text { Total concentration } \\
\text { of silicon } \\
\text { compounds (mg/L } \\
\text { solution) }\end{array}$ & $\begin{array}{c}\text { Normal } \\
\text { values } \\
\mathrm{mg} / \mathrm{L} \\
\text { solution }\end{array}$ & Calification \\
\hline Silicon & 12.12 & $5-150$ & Normal \\
\hline \multicolumn{4}{c}{ Source: INIA (2015), Basic soil fertility analysis. }
\end{tabular}

Note: The qualification is according to the optimal range of total silicon concentration according to (Zagal et al., 2007).

\section{Recommended macronutrient fertilization}

In relation to the recommendation of soil fertilization for pea crops that is detailed in table 3 , according to INIA-Huaral (2015) it recommends the adequate dose of macronutrients that is equivalent in Urea sources with $157.85 \mathrm{~kg} / \mathrm{ha}$, Diammonium Phosphate with $152.17 \mathrm{Kg} / \mathrm{ha}$ and Potassium Sulfate with $180 \mathrm{~kg} / \mathrm{ha}$. It is worth mentioning that these products are from the Molinos \& Cía brand. Likewise, the Urea fertilizer has a percentage of $46 \%$ N, Diammonium Phosphate $18 \% \mathrm{~N}$ and $46 \% \mathrm{P}_{2} \mathrm{O}_{5}$ and Potassium Sulfate with $50 \% \mathrm{~K}_{2} \mathrm{O}$.

Table 3. Recommended fertilization dose for pea crops

\begin{tabular}{clll}
\hline Culture & & \multicolumn{2}{c}{ Dose $(\mathrm{kg} / \mathrm{ha})$} \\
\hline & $\mathrm{N}$ & $\mathrm{P}_{2} \mathrm{O}_{5}$ & $\mathrm{~K}_{2} \mathrm{O}$ \\
Pea & 100 & 70 & 90 \\
\hline
\end{tabular}

Source: INIA (2015), Basic soil fertility analysis. 


\section{Journal of Sciences and Engineering}

Vol. 5, $\mathrm{N}^{\circ} 2,2021$

Copyright (C) 2021, CINCADER.

ISSN 2523-9503

DOI: https://doi.org/10.32829/sej.v5i2.134

\section{Treatment}

The availability of this nutrient in the soil was taken into account for the doses of silicon foliar fertilization, seen in table 4; which was determined by soil analysis, the dose used by farmers in the area to the pea crop and was applied at four times 15, 30, 45 and 60 days after sowing. According to Restrepo, (2015) maintains that although it has been reported that silicon is not an essential element for plant nutrition, however, since the 1960s a large amount of research has been carried out on sugar cane (Saccharum officinarum $L$ ) and rice (Oryza sativa $L$ ), crops that accumulate large amounts of silicon in the form of silica gel, which is localized in some specific tissues.

Table 4: Silicon foliar fertilization dose for pea cultivation

\begin{tabular}{cc}
\hline Treatments & $\begin{array}{c}\text { Relation between volume of } \\
\text { Silicon /volume water }\end{array}$ \\
\hline$T_{1}$ & 0.00 \\
$T_{2}$ & 0.50 \\
$T_{3}$ & 0.75 \\
$T_{4}$ & 1.00 \\
\hline
\end{tabular}

\section{Experiment procedures}

Soil samples were extracted with a shovel at a depth of $25 \mathrm{~cm}$ and in a staggered manner, then it was poured into a blanket to remove it and from there a $1 \mathrm{~kg}$ sample was taken that was taken to the National Institute of Agrarian Innovation Huaral, for analysis of soil.

The experimental area was then installed using the statistical model of the Completely Random Block Design comprised of 4 blocks and 4 treatments.

Then it was sowed with distances of $2 \mathrm{~m}$ between rows, $0.20 \mathrm{~m}$ between plants and 2 seeds per hit.

Regarding cultural tasks such as irrigation, weeding, fertilization, phytosanitary control, they were carried out in the same way for all treatments.

Regarding foliar fertilization, the doses of silicon (Sil Trade) were applied, according to the established treatments and in four moments $15,30,45$ and 60 days after sowing. These dates are indicated in table 4 and figure 2.

Data on the physical characteristics of the crop from sowing to harvest were evaluated and collected and processed by analysis of variance and Duncan's test at $5 \%$ error.

Afterwards, samples of representative leaves of each treatment were taken for their foliar analysis to INIA - Huaral, which determined which concentration of silicon obtained the highest yield. 


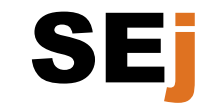

Vol. 5, $\mathrm{N}^{\circ}$ 2, 2021
Journal of Sciences and

Engineering

Copyright (c) 2021, CINCADER.

ISSN 2523-9503

DOI: https://doi.org/10.32829/sej.v5i2.134

\section{CINCADER}

Centre of Research and Training for

Regional Development

Online at www.journals.cincader.org

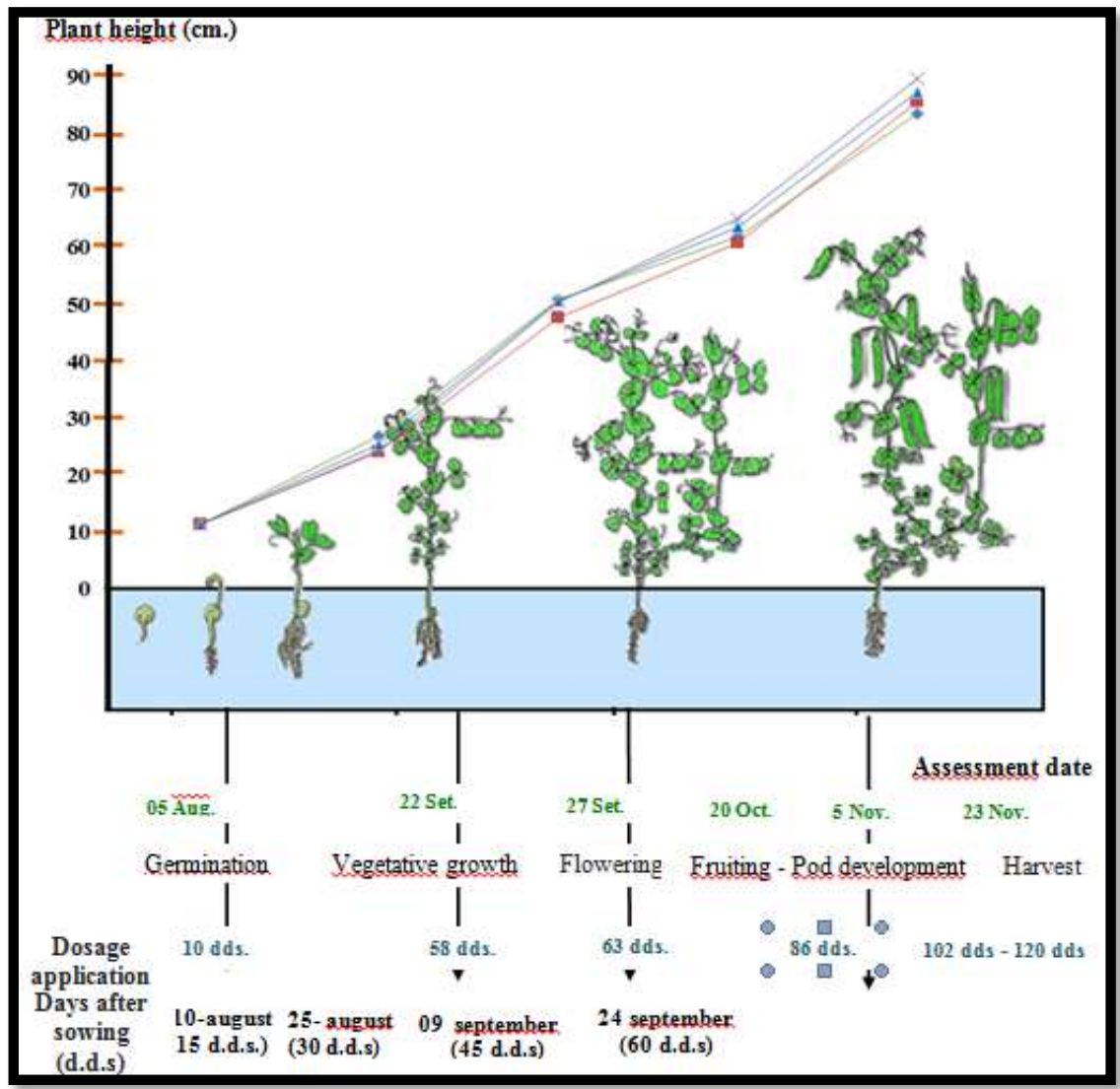

Figure 2: Date of evaluation and application of silicon doses

\section{Results}

The results obtained by each treatment both in the plant and in the soil were interpreted and analyzed, determining that the T4 with $1 \mathrm{~L}$ silicon (Sil Trade) / $200 \mathrm{~L}$ water stood out in the height, quantity and weight of pods per plant and yield. commercial. Likewise, it is specified that there was no significance; that is, the dose did not statistically influence the physical characteristics of the pea crop (see table 5).

Table 5: Physical characteristics of the pea crop according to the doses of silicon

\begin{tabular}{ccccc}
\hline Treatments & $\begin{array}{c}\text { Plant height } \\
(\mathrm{cm})\end{array}$ & $\begin{array}{c}\text { Number of pods } \\
\text { per plant }(\mathrm{N})\end{array}$ & $\begin{array}{c}\text { Pod weight } \\
\text { per plant }(\mathrm{g})\end{array}$ & $\begin{array}{c}\text { Comercial } \\
\text { performance } \\
(\mathrm{Kg} / \mathrm{ha})\end{array}$ \\
\hline $\mathrm{T}_{4}$ & $89.74 \mathrm{a}$ & $37.0 \mathrm{a}$ & $234.43 \mathrm{a}$ & $4444.4 \mathrm{a}$ \\
$\mathrm{T}_{3}$ & $87.44 \mathrm{a}$ & $35.0 \mathrm{a}$ & $225.96 \mathrm{a}$ & $4332.4 \mathrm{a}$ \\
$\mathrm{T}_{2}$ & $85.57 \mathrm{a}$ & $34.4 \mathrm{a}$ & $213.30 \mathrm{a}$ & $4232.6 \mathrm{a}$ \\
$\mathrm{T}_{1}$ & $83.44 \mathrm{a}$ & $32.0 \mathrm{a}$ & $201.78 \mathrm{a}$ & $4063.1 \mathrm{a}$ \\
Significance & ${ }_{* *}$ & ${ }_{* *}$ & ${ }_{* *}$ & 28.24 \\
VC (\%) & 11.20 & 14.69 & 30.56 & 28 \\
\hline
\end{tabular}




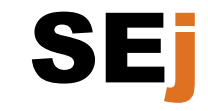

Vol. 5, $\mathrm{N}^{\circ}$ 2, 2021
Journal of Sciences and

Engineering
Centre of Research and Training for

Regional Development

Online at www.journals.cincader.org

Copyright (c) 2021, CINCADER.

ISSN 2523-9503

DOI: https://doi.org/10.32829/sej.v5i2.134

\section{Plant height}

Once the statistical operation of the plant height data was carried out by means of the statistical analysis indicated in table 5, it was determined that the T4 with $89.74 \mathrm{~cm}$ stood out in relation to the others. Likewise, it is appreciated that there was no significance; that is, the silicon doses did not influence statistically. Therefore, it is analyzed that this dose of silicon foliar fertilization favored the strengthening of the cell wall and therefore in the architecture and development of the plant, according to Villalón, et al. (2018), conclude that silicon dioxide has a positive effect on the growth and quality of piquín chili plants (Capsicum annuum L. var. Glabriusculum), resulting in superior plant quality and higher growth.

\section{Number of pods per plant}

Regarding the statistical processing of the data on the number of pods per plant that is detailed in table 5 , it is indicated that T4 with 37 pods per plant stood out in relation to the other treatments. It is also appreciated that there were no significant differences; by which it means that the silicon doses did not influence the performance. These results analyze that at this dose it promoted the absorption of other nutrients that influenced the development of the plant and therefore the yield. This analysis is supported by Furcal, et al. (2013), who conclude that silicon alone positively influences soil fertility, rice crop yield, and reduces the incidence of damage by insects and diseases.

\section{Pod weight per plant}

Regarding the statistical analysis of the weight of pods per plant that is detailed in table 5 , it is shown that T4 with $234.43 \mathrm{~g}$ of pods per plant stood out in relation to the other treatments. It is also indicated that there were no statistical differences; interpreted differently the application of silicon did not influence performance. However, at this dose it favored in the development, protection against phytosanitary and environmental stress and economic reduction of the pea crop. These results are supported by Castellanos, L. et. to the. (2015), who concluded that for more than 40 years research results have been reported on the beneficial effects of Silicon on the resistance of crops to insect pests.

\section{Business performance}

Regarding the statistical analysis of commercial yield shown in table 5, it is highlighted that T4 excelled in commercial yield with $4444.4 \mathrm{Kg} / \mathrm{ha}$. In the same way, it was determined that there was no significance; which means that the application of silicon did not statistically influence the performance. Therefore, it is analyzed that at this dose of silicon it strengthened the cell wall together with other nutrients and therefore the structure that allowed it to resist environmental, phytosanitary and nutritional stress factors, obtaining higher performance. This result is supported by Combatt, et. al (2020), who affirm that silicon ( $\mathrm{Si}$ ) is a beneficial element, because by associating with the constituents of the cell wall, it makes them less susceptible to attack by pathogens. Also Gómez, et. to the. (2006), concluded that the foliar application of honey to husk tomato seedlings favored fruit production in the presence of Fusarium oxysporum.

\section{Silicon concentration per treatment}

Concerning the concentration of silicon indicated in table 6 , the results show that T4 with $1.75 \mathrm{~g}$ of silicon / $100 \mathrm{~g}$ of dry matter stood out in the highest concentration in relation to the other treatments, according to what was analyzed by the INIA-Huaral laboratory. Therefore, this concentration of silicon promoted together with other nutrients to influence the development of the pea crop and therefore in the yield. Analyzing this result, it is based on Matichenkov, (2008), who mentions Silicon fertilizers promote the transformation of phosphates not usable by plants in available forms and prevent the transformation of phosphate fertilizers into immobile compounds. 


\section{Journal of Sciences and Engineering}

Vol. 5, $\mathrm{N}^{\circ}$ 2, 2021

Table 6. Silicon concentration by treatments $(\mathrm{g} / 100 \mathrm{~g})$

\begin{tabular}{cccccc}
\hline Treatment & $\begin{array}{c}\text { I,/200 L } \\
\text { water }\end{array}$ & Results $(\%)$ & Qualification & $\begin{array}{c}\text { Normal } \\
\text { values }\end{array}$ & $\begin{array}{c}\text { Comercial } \\
\text { performance }\end{array}$ \\
\hline $\mathrm{T}_{1}$ & 0.00 & 0.60 & Normal & $0.50-1.50$ & 4063.1 \\
$\mathrm{~T}_{2}$ & 0.50 & 0.95 & Normal & $0.50-1.50$ & 4232.6 \\
$\mathrm{~T}_{3}$ & 0.75 & 1.35 & Normal & $0.50-1.50$ & 4332.4 \\
$\mathrm{~T}_{4}$ & 1.00 & 1.75 & High & $0.50-1.50$ & 4444.4 \\
\hline
\end{tabular}

Source: INIA (2015)

\section{Conclusions}

It was determined that the foliar silicon fertilization of T4 with 1 liter of Silicon (Sil Trade) / $200 \mathrm{~L}$ of water applied in 4 moments and under the chemical characteristics of the soil of the Barranca district obtained higher yields of the pea crop with $4444.4 \mathrm{Kg} /$ has; that is, an increase of $8.59 \%$ in relation to T1; however, there was no effect of silicon doses, that is, they did not statistically influence.

The concentration of silicon per treatment was also determined in the foliar analysis, being the T4 with $1.75 \mathrm{~g}$ of silicon in $100 \mathrm{~g}$ of dry matter that stood out in relation to the others. Therefore, this result shows that this concentration of this nutrient promoted biochemical reactions together with other nutrients that favored performance.

Finally, it is concluded that the foliar fertilization of silicon in T4 with $1 \mathrm{~L}$ silicon (Sil Trade) / $200 \mathrm{~L}$ water applied in 4 moments, immediately favored the protection of the pea crop against the stress caused by environmental and phytosanitary factors and reduced the cost of production.

\section{References}

Castellanos L., De Mello R., Silva C., 2015, El Silicio en la resistencia de los cultivos. Revista Cultivos Tropicales, Volumen 36, pp. 16-24. Página web http://scielo.sld.cu/scielo.php?pid=S0258-59362015000500002\&script=sci_arttext\&tlng=pt

Combatt E., Palacio D., Blanco R., 2020, Silicio disponible en suelos alcalinos por diferentes métodos y el absorbido por cultivos de maíz y frijol a nivel de invernadero. Revista Suelos Ecuatoriales. Vol. $50 \mathrm{~N}^{\circ} 1$ y 2, pp. 13 -25 DOI: https://doi.org/10.47864/SE(50)2020p1325_114

De Carvalho V., De Meneses A., Vieira E., De Melo A., Da Silva T., De Macêdo R., Dos Santo P., De Souza L., 2019, Tratamiento de semillas con silicio sobre el crecimiento inicial de cultivares de soja (Glycine max). Revista Facultad Nacional de Agronomía Medellín, Vol. 72 $\mathrm{N}^{\circ}$ 2, pp. 8809-8817. DOI https://doi.org/10.15446/rfnam.v72n2.73226

De Freitas L., Coelho E., Mendonça S., Benetoli T., 2011, Fertilización foliar con silicio en cultivo de maíz. Revista Ceres, vol. 58, pp. 262-267. DOI https://doi.org/10.1590/S0034737X2011000200020

Epstein E., 1999, Silicio. Revisión anual de fisiología vegetal y biología molecular vegetal, Vol. 50, № 1, pp. 641-664. DOI: https://doi.org/10.1146/annurev.arplant.50.1.641 


\section{Journal of Sciences and Engineering}

Vol. 5, $\mathrm{N}^{\circ} 2,2021$

Furcal P., Herrera A., 2013, Efecto del silicio y plaguicidas en la fertilidad del suelo y rendimiento del arroz. Agronomía Mesoamericana, vol. 24, $\mathrm{N}^{\circ}$ 2, pp. 357-364. https://www.scielo.sa.cr/scielo.php?pid=S1659$13212013000200013 \&$ script=sci_arttext\&tlng=en

Gómez R., Rodríguez M., Cárdenas E., Sandoval M, Colinas M., 2006, Fertilización foliar con silicio como alternativa contra la marchitez causada por Fusarium oxysporum (Sheld) en tomate de cáscara. Revista Chapingo serie Horticultura, vol. 12, núm. 1, pp. 69-75. https://www.redalyc.org/pdf/609/60912111.pdf

Google maps., 2021, Ubicación del área experimental, Mapa google. Página web https://www.google.es/maps/place/10\%C2\%B046'05.1\%22S+77\%C2\%B044'30.0\%22W/@$10.768082,-$

77.7422139,183m/data=!3m2!1e3!4b1!4m15!1 m8!3m7!1s0x0:0x0!2zMTDCsDQ2JzA0LjYiUy A3N8KwNDQnMjkuNCJX!3b1!7e2!8m2!3d-10.7679343!4d-

77.7414903 !3m5!1s0x0:0x0!7e2!8m2!3d-10.7680867!4d-77.7416743

Instituto Nacional de Innovación Agraria (INIA-Huaral), 2015, Análisis básico fertilidad de suelos, para el cultivo de arveja en el distrito de Barranca. Hoja de resultados de análisis. Perú.

Instituto Nacional de Innovación Agraria (INIA-Huaral), 2015, Análisis foliar de silicio, para el cultivo de arveja en el distrito de Barranca. Hoja de resultados de análisis. Perú

Matichenkov, V., 2008, Deficiencia y funcionalidad del sílice en suelos, cosechas y alimentos. Investigación. Instituto de Problemas Biológicos Básicos II Conferencia internacional sobre ecología del suelo y el compost; $26-29$, noviembre; Tenerife. http://massamllc.com/newsite/wp-content/uploads/2016/07/DEFICIENCIA-Y-

FUNCIONALIDAD-DEL-SI\%CC\%81LICE-EN-SUELOS-COSECHAS-Y-ALIMENTOS.pdf

Michajluk J., Gómez R., Moreno H., Leguizamón C., Cabello J., 2019, Evaluación del contenido de silicio en suelo a través de técnicas analíticas nucleares. Revista Científica de la UCSA (Universidad del CONO sur de las Américas), vol. $6 \mathrm{~N}^{\circ} 3$, pp. 18-22. DOI: https://doi.org/10.18004/ucsa/2409-8752/2019.006.03.018-022

Molina, E., 2002, Fuentes de fertilizantes foliares, Fertilización Foliar: Principios y Aplicaciones. Libro de Memoria, Laboratorio de suelos y foliares, 2002, pp. 1-14. http://www.cia.ucr.ac.cr/pdf/Memorias/Memoria\%20Curso\%20Fertilizaci\%C3\%B3n\%20Foliar .pdf

Quero, E., 2008, Silicio en la producción agrícola. Instituto Tecnológico Superior de Uruapan, Carapan N5555, Col. La Basilia, Uruapan, Michoacán. Consultado 15 -08-2021 Página web https://sites.google.com/site/ccmjns/i-d/el-silicio

Restrepo F., Cristancho J., 2015, Importancia agronómica del silicio y su impacto en la productividad de la caña de azúcar. Suelos ecuatoriales Vol. $45 \mathrm{~N}^{\circ} 1$. pp. 10-15. http://unicauca.edu.co/revistas/index.php/suelos_ecuatoriales/article/view/13/11

Savant N., Snyder G., Datnoff L., 1996, Manejo de silicio y producción sustentable de arroz. Avances en Agronomía, Vol. 58, 1996, pp. 151-199. DOi: https://doi.org/10.1016/S00652113(08)60255-2

Villalón H., Castillo M., Garza F., Guevara J., Sánchez L., 2018, Dióxido de silicio como estimulante del índice de calidad de plantas de chile piquín (Capsicum annuum L. var. 


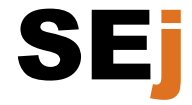

Vol. 5, $\mathrm{N}^{\circ}$ 2, 2021

\section{Journal of Sciences and \\ Engineering}

Copyright (c) 2021, CINCADER.

ISSN 2523-9503

DOI: https://doi.org/10.32829/sej.v5i2.134

glabriusculum) producidas en vivero. Revista Mexicana de Ciencias Forestales, vol. $9 \mathrm{~N}^{\circ} 50$, pp. 294-303, DOI. https://doi.org/https://doi.org/10.29298/rmcf.v9i50.247

Zagal E., Sadzawka A., 2007, Protocolo de métodos de análisis para suelos y lodos. Documento. Universidad de Concepción, Servicio Agrícola y Ganadero: Santiago, Chile. http://www.sag.cl/sites/default/files/METODOS_LODOS_SUELOS.pdf

\section{CINCADER}

Centre of Research and Training for

Regional Development

Online at www.journals.cincader.org 